\title{
IDENTIFICATION AND EVALUATION \\ OF PROFESSIONAL RISK AT THE ENTERPRISE BY METHOD OF OPERATION SAFETY AND EFFICIENCY
}

\author{
N. Volodchenkova \\ National University of Food Technologies
}

Key words:
Danger
Risk
Decision
Efficiency
Management

Article history:

Received 03.07.2018

Received in revised form

20.07.2018

Accepted 16.08.2018

Corresponding author:

N. Volodchenkova

E-mail:

volna22@bigmir.net

\begin{abstract}
Statistics on labour safety in Ukraine indicate that the level of injury remains at a high level. One of the important parts of the activity of any enterprise of food industry is the analysis and prevention or dangerous situations that can lead to industrial injury, occupational disease or death of the employee. In order to control and minimize risk that may be the reason of accidents identification and evaluating the risk of the company, arising in the course of the production activity are carried out.
\end{abstract}

Results of the analysis of international standards about management of risks are presented in the paper and methods of identification and prejudice the dangers by functional analysis of the dangers are given. The algorithm of identification and register of risks is developed. During the identification of potential danger, the key and control words for each stage (segment) of technological process and determine the possible deviation, reasons and consequences of these deviations and loss as a result of possible deviations is proposed to use. A matrix of possible deviations is developed. Based on the analysis of in order to prejudice possible dangers measures are developed and responsible person that control stage of the technological process is appointed.

Identifying and evaluating the production risks will prevent from dangerous situations, cases of injury and occupational diseases, that will ensure the preservation of health and life of workers and the welfare of the whole enterprise. The strategy, which is aimed at risk management, will provide the opportunity to determine for the enterprise, just those risks that are potentially able to cause serious negative consequences.

DOI: $10.24263 / 2225-2924-2018-24-4-16$ 


\title{
ІДЕНТИФІКАЦІЯ ТА ОЦІНЮВАННЯ ПРОФЕСІЙНОГО РИЗИКУ ПІДПРИЕМСТВА МЕТОДОМ ЕКСПЛУАТАЦІЙНОЇ БЕЗПЕКИ І ПРАЦЕЗДАТНОСТІ
}

\author{
Н.В. Володченкова \\ Наиіональний університет харчових технологій
}

Статистичні дані з питань безпеки прачі в Украӥні свідчать про те, що рівень травматизму залишається досить високим. Однією з важливих ланок діяльності будь-якого підприємства харчової промисловості є аналіз $i$ запобігання ризику виникнення небезпек або небезпечних ситуацій, що можуть призводити до виробничої травми, профзахворювання або загибелі прачівника. 3 метою контролю та мінімізації джерел ризику, щь можуть бути причиною нещасних випадків, проводиться ідентифікаџія й оцінення ризиків на підприємстві, які виникають у процесі виробничої діяльності.

У статті представлено результати аналізу міжнародних стандартів 3 менеджменту ризиків і наведено методику ідентифікаиії та запобігання небезпекам методом функиіонального аналізу дослідження небезпек $і$ прачездатності. Розроблено алгоритм ідентифікаиії та реєстру ризиків. При проведенні ідентифікаиії можливих небезпек пропонується використовувати ключові та керуючі слова для кожної стадії (сегмента) технологічного проиесу та визначати можливі відхилення, причини та наслідки ичих відхилень $i$ втрати внаслідок можливих відхилень. За результатами складається матриия можливих відхилень. На основі проведеного аналізу розробляються заходи з метою запобігання можливим небезпекам і призначається відповідальна особа, що контролює стадію технологічного процесу та не допускає відхилення необхідних параметрів.

Визначення й оцінення виробничих ризиків запобігатиме виникненню небезпечних ситуачій, випадкам травматизму та професійних захворювань, що забезпечить збереження здоров'я й життя робітників $i$ благополуччя всього підприємства. Стратегія, направлена на ризик-менеджмент, дасть змогу визначити для підприємства саме ті ризики, які потенційно здатні викликати серйозні негативні наслідки.

Ключові слова: небезпека, ризик, рімення, оперативність менеджмент.

Постановка проблеми. Сучасний стан інтенсивного розвитку харчової промисловості, з огляду на збільшення об'ємів виробництва та розширення асортименту продукції, призводить до появи цілого комплексу нових небезпек, суттєвого підвищення ступеня ризику травматизму та загибелі людей. Важливе значення для збереження здоров'я та працездатності працівників $\epsilon$ запобігання виникненню таких небезпек. Створення безпечних умов праці досягається шляхом впровадження найкращих світових практик в інтегровані системи управління промисловим підприємством на основі міжнародних стандартів з менеджменту ризику. 
Мета дослідження: провести аналіз діючих методик дослідження ризику небезпек та удосконалити метод виявлення та запобігання виробничим ризикам, що забезпечить зниження рівня виробничого травматизму.

Матеріали і методи. При вирішенні поставленого завдання використовувалися якісний метод функціонального аналізу HAZOP (Hazard and Operability Stud) - дослідження небезпек i працездатності та методи «дерево причин», «дерево подій», «дерево відмов», «дерево небезпек» при процедурі виявлення причин аварій, травм, пожеж та інших випадків.

Результати і обговорення. Для збереження трудового потенціалу та уникнення зайвих втрат, пов'язаних з професійних травмами і захворюваннями, Міжнародна організація стандартизації (ISO) допомагає підприємствам виявляти небезпеки, розробивши для цього стандарти з ризик-менеджменту серії ISO, що можуть застосовуватися в організаціях усіх видів незалежно від форм власності, видів діяльності та обсягів виробництва.

У Європейському Союзі ризик-орієнтований підхід закріплено стст. 2, 3 Європейської соціальної хартії (переглянутої), а також так званою «рамковою» Директивою № 89/391/СЕС Ради щодо встановлення заходів із заохочення поліпшення охорони здоров'я та безпеки праці працівників.

Задля встановлення соціальної справедливості, дотримання міжнародновизнаних прав людини і прав у сфері праці Україна ратифікувала понад 170 конвенцій, в тому числі 8 фундаментальних [1]

Для того, щоб подолати проблеми порушень у сфері охорони праці і покращити бізнес-клімат в Україні, Мінекономрозвитку розробило та затвердило Стратегію реформування системи державного нагляду (контролю). Її головна мета - перетворити систему нагляду і контролю на систему управління ризиками. Стратегія передбачає вдосконалення ризик-орієнтованого підходу, переорієнтацію інспекційної системи на запобігання порушенням та підвищення відповідальності інспекторів (затверджена розпорядженням Кабінету Міністрів України від 18 грудня 2017 року № 1020-р [2].

Визначення та оцінення виробничих ризиків запобігатиме виникненню небезпечних ситуацій, випадкам травматизму та професійних захворювань, що забезпечить збереження здоров'я й життя робітників і благополуччя всього підприємства. Стратегія, направлена на ризик-менеджмент, дасть змогу визначити для підприємства саме ті ризики, які потенційно здатні викликати серйозні негативні наслідки.

На сьогодні серія ISO 31000 представлена такими стандартами, рекомендаціями й технічними висновками в галузі ризик-менеджменту:

ДСТУ ISO 31000:2014 Менеджмент ризиків. Принципи та керівні вказівки. (ISO 31000:2009);

ДСТУ ISO Guide 73:2013 «Керування ризиком. Словник термінів»;

ДСТУ IEC/ISO 31010:2013 Керування ризиком. Методи загального оцінювання ризику (IEC/ISO 31010:2009, IDT);

ISO/TR 31004:2013 «Менеджмент рисков. Руководство по внедрению ISO $31000 »$;

ISO 45001:2018 «Менеджмент охорони здоров’я та безпеки праці Вимоги та настанови щодо застосовування». 
Найбільш вагомим є стандарт ДСТУ IEC/ISO 31010:2013 «Керування ризиком. Методи загального оцінювання ризику». Цей стандарт описує принципи вибору методу загального оцінювання ризиків, які можна визначати за зміною ступенів глибини і докладності, використовуючи один чи кілька методів - від найпростіших до найскладніших.

Стандарт описує 31 метод дослідження ризиків, які у загальному можна згрупувати за змістом:

1. Креативні (мозковий штурм; метод Делфи; структуроване або напівструктуроване інтерв'ю).

2. Аналіз сценаріїв (аналіз причин і наслідків; аналіз дерева відмов; аналіз дерева події; аналіз сценаріїв; дерево рішень; аналіз рівня захисту; аналіз ризику для навколишнього середовища тощо).

3. Аналіз індикаторів (чек-листи; CIRS; CBRM).

4. Функціональний аналіз (FMEA; аналіз небезпек; HAZOR; HACCP; аналіз людської надійності).

5. Статистичні методи аналізу (FN крив; аналіз Маркова; метод Монте-Карло; статистика Бейса і мережі Бейса).

Так, для харчових підприємств обов'язковою умовою діяльності $\epsilon$ впровадження міжнародних норм з ризик-менеджменту. Зокрема, з 20 вересня 2016 року відповідно до розділу VII Закону України «Про основні принципи та вимоги до безпечності та якості харчових продуктів» - Загальні гігієнічні вимоги щодо поводження з харчовими продуктами передбачають впровадження програм-передумов системи НАССР (Hazard analysis and critical control points) - аналіз ризиків і критичні контрольні точки - стандарт гігієнічних вимог системи менеджменту харчової безпеки.

У системі визначення менеджменту якості використовується метод FMEA (Failure Mode and Effects Analysis) - аналіз видів і наслідків відмов. Це метод структурованого підхіду до виявлення потенційних відмов (дефектів), які можуть існувати при створенні продукту або розробці процесу.

FMECA (FailureMode, Effects and Criticality Analysis) - аналіз видів, наслідків та критичності відмов) розширює FMEA і включає в себе методи ранжирування тяжкості видів відмов, дозволяє встановити пріоритетність контрзаходів. Поєднання тяжкості наслідків і частоти виникнення відмов $€$ критичністю (кожний вид відмови ранжується з урахуванням двох складових критичності-ймовірності і важкості наслідків відмови) [3-5].

Для дослідження ризику у сфері промислової безпеки та охорони праці використовують метод HAZOP (Hazard and Operability Stud) - дослідження небезпек та працездатності. Це якісний метод оцінення, метою якого $\epsilon$ ідентифікація небезпек (відмов елементів системи), а також їх причин і наслідків. Процес оцінки проводиться шляхом умовного подрібнення дослідної системи на складові частини (підсистеми, елементи, компоненти, вузли) та їхнього подальшого аналізу з метою визначення можливого стану відхилення системи в умовах впливу тих чи інших небезпечних факторів, номенклатури таких факторів, а також ймовірності виникнення відповідних небажаних наслідків. 
Аналіз експлуатаційної безпеки та працездатності (HAZOP) заснований на теорії, яка припускає, що випадки ризику є наслідком відхилення від запланованих або робочих параметрів.

На кожному підприємстві харчової промисловості, при відсутності або нестачі статистичних даних про ризики пропонується ідентифікувати та реєструвати можливі ризики. Процедуру ідентифікації та реєстру ризиків проводять за схемою (рис. 1).

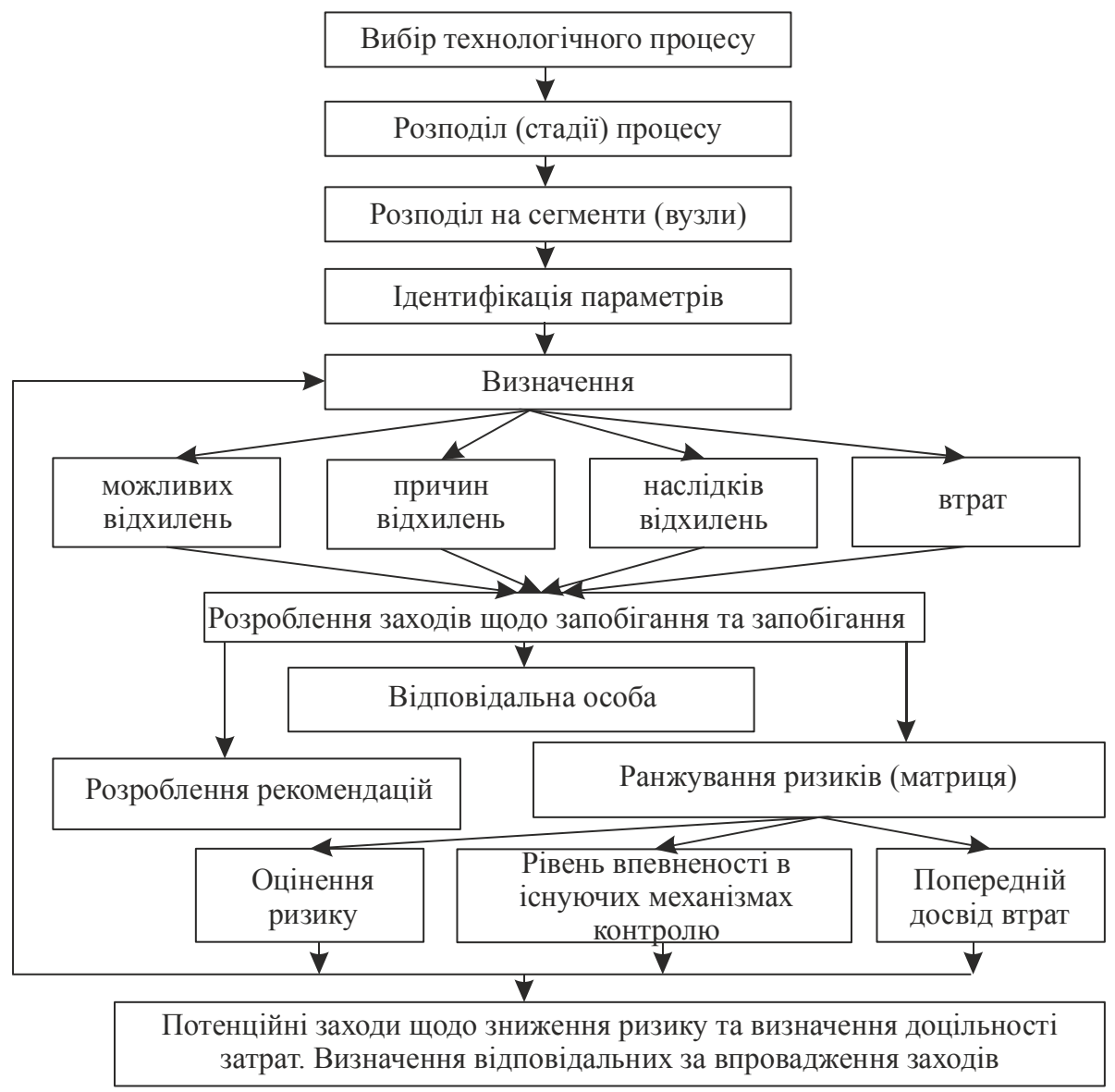

Рис. 1. Блок-схема ідентифікації та ресстру ризиків

Перевагами методу HAZOP є забезпечення детального та комплексного дослідження системи, що, у свою чергу, створює передумови для всебічної оцінки ризику, в тому числі дає змогу достатньо детально оцінити можливі причини та наслідки помилок системи (вплив «людського фактора»). Залучення ж до виконання процесу оцінки фахівців з досвідом практичної роботи у суміжних галузях безумовно підвищує ступінь ії об'єктивності. Також перевагою методу є можливість його поетапного застосування для досить широкого спектра процесів і систем, а реєстрація проміжних результатів дає змогу 
більш детально проаналізувати певні етапи досліджень у разі виникнення спірних чи небажаних результатів [6;7].

Послідовність виконання процедури виявлення небезпек у системі HAZOP базується на першочерговому виділенні комбінацій технологічних параметрів процесу (наприклад: «тиск», «температура», «швидкість» тощо) і використанні ключових і керуючих слів («так», «ні», «занадто рано», «занадто», «більше», «менше» тощо), які дають змогу дослідити та виявити можливі зміни (відхилення) елементів системи від нормального режиму роботи. Такі ключові слова застосовують (рис. 2):

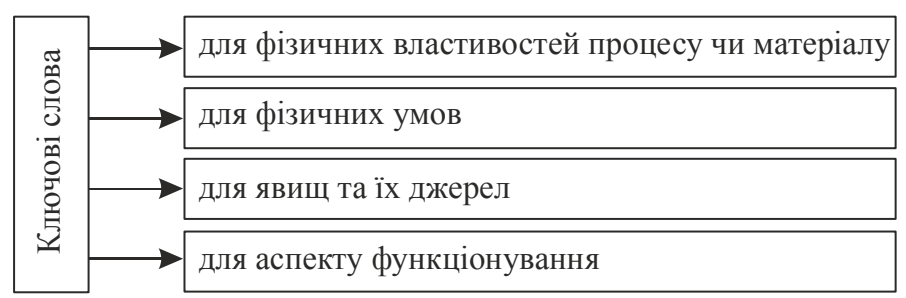

Рис. 2. Параметри використання ключових слів

Приклад матриці відхилень при визначенні небезпек ризику відхилення дії тиску (табл. 1).

\section{Таблиия1. Матриця відхилень тиску}

\begin{tabular}{|c|c|c|c|c|c|c|}
\hline \multirow{2}{*}{$\begin{array}{c}\text { Параметр } \\
\text { процесу }\end{array}$} & \multicolumn{7}{|c|}{ Керуюче слово } \\
\cline { 2 - 7 } & Тільше & Менше & Нi & Так & Ніяких & Інше \\
\hline \multirow{2}{*}{ Тиск } & $\begin{array}{c}\text { Високий } \\
\text { тиск }\end{array}$ & $\begin{array}{c}\text { Низький } \\
\text { тиск }\end{array}$ & $\begin{array}{c}\text { Атмосферний } \\
\text { тиск }\end{array}$ & $\begin{array}{c}\text { Нормоване } \\
\text { значення }\end{array}$ & Вакуум & $\begin{array}{c}\text { Зміна інших } \\
\text { парметрів }\end{array}$ \\
\hline
\end{tabular}

Кожне керуюче слово має своє значення при визначенні відхилень. Значення керуючих слів представлено у табл. 2 [8].

\section{Таблиия 2. Значення керуючих слів}

\begin{tabular}{|c|c|}
\hline Керуюче слово & Значення \\
\hline Більше & $\begin{array}{c}\text { Кількісне збільшення показників параметра (наприклад: перевищення } \\
\text { тиску у трубопроводі) }\end{array}$ \\
\hline Менше & $\begin{array}{c}\text { Кількісне зменшення показників параметра (наприклад: зниження } \\
\text { тиску у трубопроводі) }\end{array}$ \\
\hline $\mathrm{Hi}$ & $\begin{array}{l}\text { Не виконується цільове призначення (функція) елемента (підсистеми, } \\
\text { компонентів, вузла). Параметр не реалізовується. (наприклад: відсутій } \\
\text { тиск у трубопроводі) }\end{array}$ \\
\hline Зворотне (ніяких) & $\begin{array}{l}\text { Змінення праматерів на протилежне (наприклад: вакуум } \\
\text { у трубопроводі) }\end{array}$ \\
\hline Інше & $\begin{array}{c}\text { Дія, що відрізняється від проектного значення; результат не відповідає } \\
\text { меті (наприклад: відсутність речовини у трубопроводі) }\end{array}$ \\
\hline
\end{tabular}

У разі виявлення таких відхилень з’ясовуються причини, які їх викликали, визначаються можливі наслідки настання небезпечної події та розробляються заходи щодо усунення таких причин або (за неможливості їх усунення) мінімізації важкості наслідків. 


\section{Висновки}

Впровадження найкращих світових практик в інтегровані системи управління підприємств харчової промисловості на основі міжнародних стандартів 3 менеджменту ризику створить безпечні умови праці, знизить ризики виникнення нещасних випадків, аварій та аварійних ситуацій, скоротивши таким чином витрати підприємства, та дасть змогу працівникам відчути, що їхні потреби щодо професійної безпеки враховуються.

Методика ідентифікації та реєстру ризиків HAZOP надає можливість визначити небезпеки як на стадії проектування процесу, системи або елемента, так і в безперервному процесі виготовлення продукції. За цією методикою легко визначити нові параметри відхилення та наслідки у разі зміни обладнання, технології чи елемента системи шляхом доповнення контрольного листа зі складанням матриці відхилень.

Поруч із позитивними сторонами методики хотілося б відмітити і негативні сторони, які виникають при розробленні таких матриць небезпек, - це занадто трудомісткий процес і надлишкова кількість сценаріїв розвитку й наслідків виникнення небезпек.

\section{Література}

1. Офіційний сайт Міжнародної організації праці (МОП) [Електронний ресурс]. — Peжим доступу : http://geneva.mfa.gov.ua/ua/ukraine-io/labour.

2. Розпорядження КМУ «Про схвалення Стратегії реформування системи державного нагляду (контролю)» [Електронний ресурс]. — Режим доступу : http://zakon0.rada.gov.ua/laws/show/1020-2017-\%D1\%80.

3. Лис Ю.С. Оцінка ризиків в системі управління охороною праці / Системи обробки інформації. - 2016. - Випуск 9(146). - С. 193-196.

4. Цьопа В. Ризик-орієнтоване мислення: основи, навчання та впровадження. — Київ : Охорона праці, 2017. - № 8-10. - С. 25-32.

5. Богданова О.В. Комбінований метод оцінки ризику травматизму для промислового підприємства / О.В. Богданова // Проблеми охорони праці в Україні : зб. наук. праць. — Київ : ДУ «ННДІПБОП», 2016. - Вип. 31. - С. 52-63.

6. Бочковський А.П. Теоретичні аспекти універсалізації оцінки професійного ризику в системах управління охороною праці // Вісник ЛДУ БЖД. — 2016. — № 14. — С. 134151.

7. Paul Baybutt A critique of the Hazard and Operability (HAZOP) study// Journal of Loss Prevention in the Process Industries, Vol. 33, January 2015, Pages 52-58.

8. Лисанов М.B. Применение методов анализа опасностей HAZID и HAZOP при проектировании газотранспортного терминала / М.В. Лисанов, В.В. Симакин, А.И. Макушенко, П.И. Дворниченко, А.В. Еремеев-Райхерт // Безопасность труда в промышленности. 2008. 一№ 8. - С. 63 - 69 . 